\title{
SIZE AND FISHING GROUND OF WAHOO (Acanthocybium solandri Cuvier, 1832) FROM CATCH DATA OF TUNA LONGLINE OPERATED IN INDIAN OCEAN
}

\author{
${ }^{1)}$ Agustinus Anung Widodo, ${ }^{2)}$ Fayakun Satria and ${ }^{3)}$ Budi Nugraha \\ 1) Research Center for Fisheries Management and Conservation \\ 2) Research Institute for Fish Resources Rehabilitation and Conservation \\ 3) Research Station for Tuna Fisheries \\ Received February 2-2012; Received in revised form December 4-2012; Accepted December 5-2012 \\ E-mail: anungwd@yahoo.co.id
}

\begin{abstract}
Wahoo (Acanthocybium solandri Cuvier, 1832) is a member of the Scombrid family, is a pelagic (open ocean) species found worldwide in tropical and warm-temperate seas. It is fished throughout its range by artisanal, recreational, and commercial. Wahoo is one of the by-product species of the tuna long line fleets operate in Indian Ocean. This paper describes status of wahoo resource caught by tuna long line in Indian Ocean based at Benoa-Bali. Data obtained from onboard observer program on the tuna long liner based at Benoa-Bali during 2005-2010. Total of 85 trips of onboard observation were carried out with the total long line sets (one set per day) were 2873 times. The data covered the horizontal and vertical position of tuna long line hooks caught the wahoo, hook rate and fish size distribution. Data of horizontal fishing positions (coordinates) gained from the global positioning system availabled in the tuna long liners. The depth of the long line gear in the waters and teperature of waters were measured by mini-loggers TDR type SP2T-1200, brand: NKE Micrel. Hook rate of wahoo is calculated using the Klawe (1986) method. Result of research showed that the wahoos

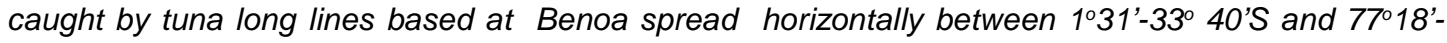
$117^{\circ} 53^{\prime} \mathrm{E}$ and spread vertically between the depth of $75.2-285.7 \mathrm{~m}$. From 85 tuna long line fishing trips, only about $50 \%$ of 85 tuna long line fishing trips caught wahoo with hook rate ranged 0.947-1.399 per 1000 hooks/setting. Size distribution of wahoo ranged $70-180 \mathrm{~cm}$ with modus ranged $101-110 \mathrm{~cm}$.
\end{abstract}

Keyword: Wahoo, tuna long line, indian ocean

\section{INTRODUCTION}

Wahoo (Acanthocybium solandri Cuvier, 1832) is known as Pacific kingfish, tiger fish, ocean barracuda, Malata kingfish, queenfish, kingfish. Fishermen in Hawaii called as ono and peto by fishermen in Karibia. Indonesian fishermen in general called wahoo as tengiri, and tuna long line fishermen in Benoa-Bali called as nyunglas. Collette \& Nauen (1983) described the short description of wahoo as follows, number of dorsal spines (D.XXII-XXVII.12-16), no anal spines, anal soft rays (A.12-14), vertebrae 62 - 64. Mouth large with strong, triangular, compressed and finely serrate teeth. Snout about as long as the rest of head. Posterior part of maxilla completely concealed under pre-orbital bone. Gill rakers absent. Inter-pelvic process small and bifid. Swim bladder present. Body covered with small scales. No anterior corselet developed. The back is iridescent bluish green; the sides silvery with 24 to 30 cobalt blue vertical bars which extend to below the lateral line.

Wahoo (Acanthocybium solandri Cuvier, 1832), a member of the Scombrid family, a pelagic (open ocean) species found worldwide in tropical and warm- temperate seas. The wahoo is highly migratory species, widely distributed throughout tropical and subtropical oceans (Collette \& Nauen, 1983; Garber et al., 2005; Mc Bride et al., 2008). Roullot \& Venkatasami, (1986) mentioned that sports fishermen used troll around FAD reported good catches of tuna, dolfinfish and wahoo. The major non-tuna catch of what could be considered as the three small-scale fisheries in the region targeting tuna (i.e. those in Cape Verde, Morocco and South Africa) show great differences between the countries. Mostly wahoo in Cape Verde mostly Sarda in Morocco, and almost no non-tuna catch by the small-scale tuna fishery in South Africa (Gillet, 2011). In Indonesia wahoo primarily harvested as bycatch in the troll line, drift gillnet, and tuna long line and purse seine fisheries. This paper describes status of wahoo resource caught by tuna long line in Indian Ocean based at Benoa-Bali.

\section{MATERIALS AND METHODS}

Data analyzed were obtained from onboard observer program on commercial tuna long line fleets based at Benoa-Bali in the period August 2005 to October 2010. Mostly tuna longlines technology 
based at Benoa are using monofilament line that was first introduced into Indonesia by Taiwanese in 1990s. The principal parts of tuna long line consist of a continuous monofilament main line, with floats and branch lines commonly made of smaller gauge monofilament. Numbers of branch line (hook) in between floats were 12 with interval of each branch lines were $50 \mathrm{~m}$. The lengths of each branch lines are 25-30 meter. The deepest hooks usually reach $400 \mathrm{~m}$ with target species yellowfin tuna (Thunnus albacares) and bigeye tuna (Thunnus obesus), whereas wahoo (Acanthocybium solandri) was one species caught as by-product. Total of 85 trips were carried out with the total long line sets (one set per day) of 2873 times. The tuna long line equipped with radio beacons, radar reflectors, and strobe lights are more likely to be used in marking the gear.

The depth of the long line gear in the waters and temperature of waters were measured by 6 miniloggers TDR type SP2T-1200, brand: NKE Micrel. The minilogger provide information on depth and water temperature, capable to record water depth up to1200 $\mathrm{m}$ and the water temperature -5 to $35^{\circ} \mathrm{C}$. The miniloggers attached in the end of branch lines (clossed to the hooks). The setting configuration of minilogger was attached to the $1^{\text {st }}, 2^{\text {nd }}, 3^{\text {rd }}, 4^{\text {th }}, 5^{\text {th }}$ and $6^{\text {th }}$ branch lines respectively on each basket (Figure 1). With this minilogger setting configuration, each depth range would be covered and recorded.

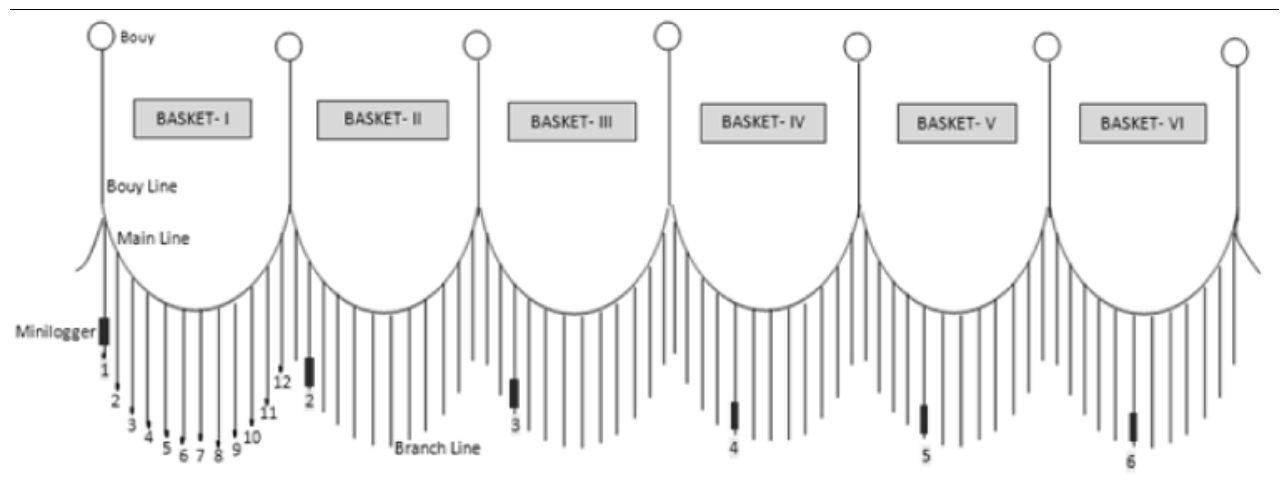

Figure 1. The setting configuration of the minilogger on the branch line of tuna long line during research.

Indentification fish species refer to Collete \& Nauen (1983), Compagno (1999), Sainsbury et al. (1985) and Sommer et al. (1996). The hook rate was calculated by using the equation of Klawe (1986) as follows:

$$
H R=\frac{J I}{J P} x A
$$

$$
\begin{aligned}
\text { where: HR } & =\text { hook rate. } \\
\text { Jl } & =\text { number of fish caught. } \\
\text { JP } & =\text { number of hook sets. } \\
\text { A } & =1000 .
\end{aligned}
$$

\section{RESULTS}

\section{Horizotal and Vertival Distribution}

Horizontal distribution of wahoo can be described base on result of onboard observer program in 20052010. The wahoo caught by tuna long line based at

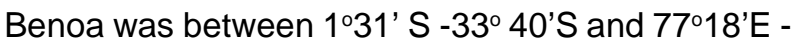
117053'E. In 2005-2006, tuna long line based at BenoaBali caught wahoo on $12^{\circ} \mathrm{S}-16^{\circ} \mathrm{S}$ and $107^{\circ} \mathrm{E}-116^{\circ} \mathrm{E}$. In 2007, wahoo caught by tuna long line on the area $11^{\circ} \mathrm{S}-34^{\circ} \mathrm{S}$ and $97^{\circ} \mathrm{E}-115^{\circ} \mathrm{E}$. In 2008 , area where wahoos were caught $1^{\circ} \mathrm{S}-15^{\circ} \mathrm{S}$ and $76^{\circ} \mathrm{E}-116^{\circ} \mathrm{E}$, whereas in 2009 wahoo caught on the area $1^{\circ} \mathrm{S}-14^{\circ} \mathrm{S}$ and $96^{\circ} \mathrm{E}-117^{\circ} \mathrm{E}$. In 2010 wahoo caught in area $1^{\circ} \mathrm{S}$ $13^{\circ} \mathrm{S}$ and $96^{\circ} \mathrm{E}-120^{\circ} \mathrm{E}$ (Figure 2).

The information on vertical distribution of wahoo was identified through the depth of hook which caught the wahoo. The longline fishing experiment appears as a relevant methodology to achieve this goal (Bach et al., 2003). Installation the miniloger on the branch line of tuna long line has been widely used to obtain the information of vertical distribution as used in this research. Result of research show that the wahoo caught by tuna long line spreads between the depths ranged $75-286 \mathrm{~m}$ and mostly caught at depths ranged 100-150 m (Figure 3). 


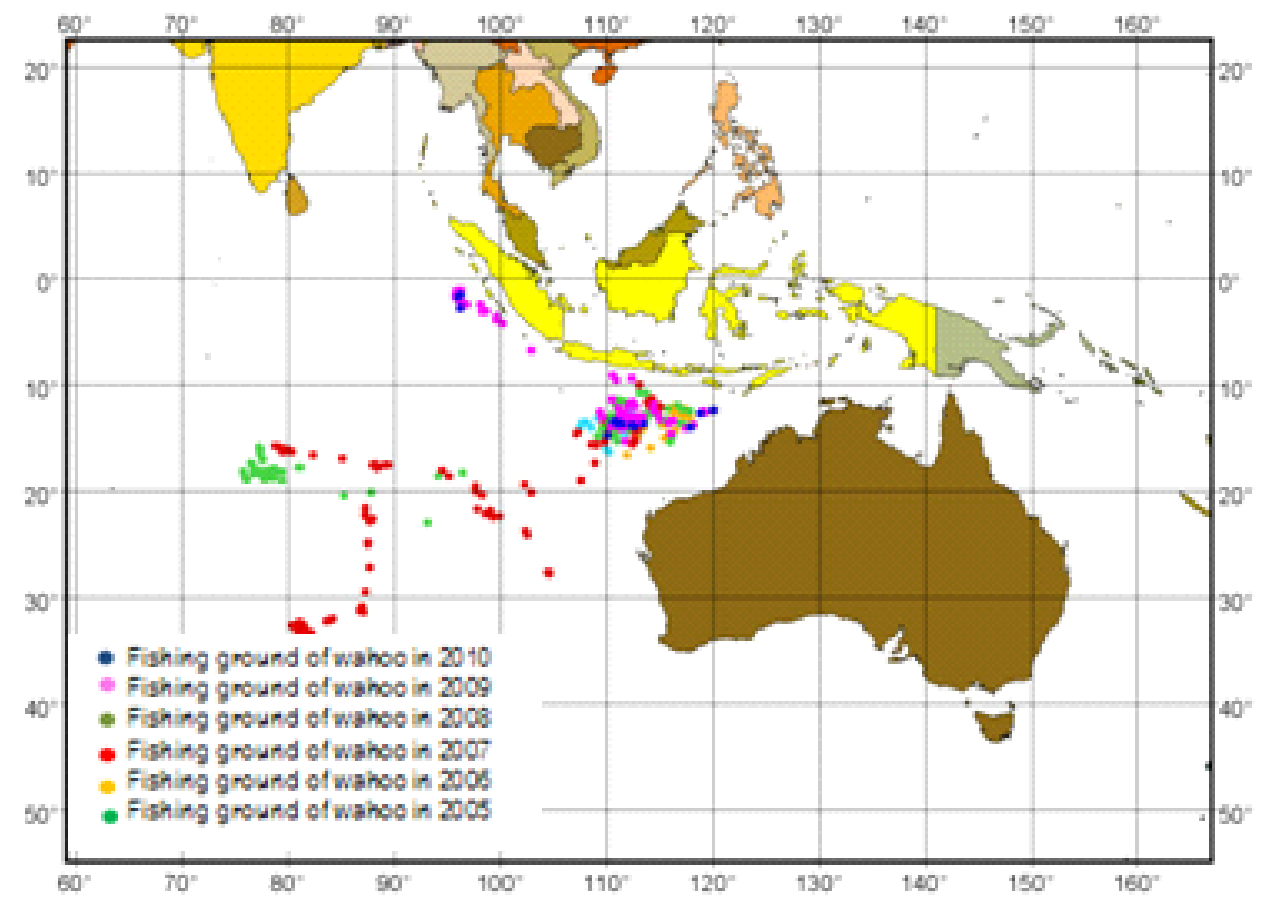

Figure 2. Position of wahoo caught by tuna long line during onboard observer program (2005-2010) which also describes the potential of horizontal distribution of Wahoo.

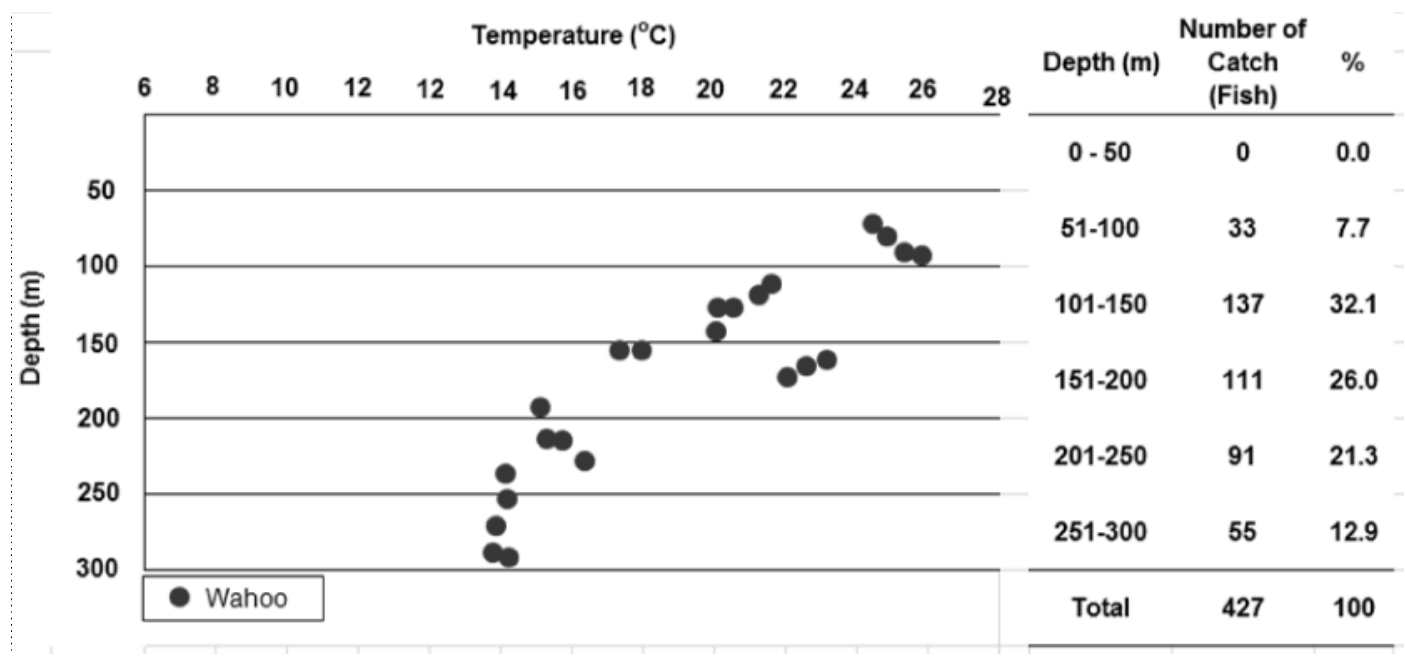

Figure 3. Depth range that caught by tuna long line during onboard observer program (2005-2010) which also describes the potential of vertical distribution of Wahoo.

Wahoo is a pelagic, highly migratory species of the family scombridae which broadly distributed throughout tropical and subtropical oceans (Collette and Nauen 1983; Garberetal. 2005; Mc Bride et al., 2008). Little information is available on wahoo movement, although their availability change seasonally and the average size different in the various latitude. Wahoo may also migrate seasonally away from the equator following oceanic temperature patterns (Iverson \& Yoshida, 1957).
Previous study by Nakano et al. (1997) noted that the catch rate of wahoo in the long line fishery varies at different depth and further argued that wahoo was surface oriented i.e. < 160 meters depth. It is reinforced by evidence the most of wahoo caught by long lines predominantly in the surface (Nakano et al. 1997; Beverly et al., 2009). Sepulveda et al. (2011) noted that depths layer of wahoo is up to $253 \mathrm{~m}$, but in this study recorded that the maximum depth layer of wahoo recorded up to $285.7 \mathrm{~m}$. NMFS (2001) noted 
that the distribution of wahoo is associate with warm, productive oceanic fronts, especially when these fronts are near coastal shelves and banks.

\section{Hook Rate}

From 85 tuna long line fishing trips, only 42 fishing trips those caught wahoo with total number of catch of wahoo was 463 fishes Hook rate ranged 0.947 1.399 per 1.000 hooks/setting (Table1, Figure 4). The hook rate is higher compared to the hook rate of wahoo on the tuna long line operated in Pacific Ocean as reported by Kim et al. (2007) that the hook rate on the tuna long line operated in Pacific Ocean was 0.446 per 1.000 hooks. The other previous research noted that only 12 wahoo were caught during 5,500 hours of surface trolling in the open sea, more than 60 miles from coastal (Murphy \& Ikehara 1955: 14). This species is known to travel solitarily or in small schools of two to twenty fish (Iverson and Yoshida 1957), and is attracted to banks, pinnacles and islands, as well as flotsam drifting in the open ocean (NMFS 2001). That condition allegedly as one of the reasons the hook rate of wahoo on the tuna long line was very low.

Table 1. Hook rate of wahoo on the tuna long line year 2006-2010 based on onboard observer program.

\begin{tabular}{rrrc}
\hline Year & $\begin{array}{c}\text { Number } \\
\text { of Hooks }\end{array}$ & $\begin{array}{c}\text { Catch of } \\
\text { Wahoo } \\
\text { (Fish) }\end{array}$ & $\begin{array}{c}\text { Hook Rate } \\
\text { (Fish/1000 } \\
\text { hooks) }\end{array}$ \\
\hline \hline 2005 & 14145 & 15 & 1.060 \\
2006 & 25854 & 25 & 0.966 \\
2007 & 121877 & 122 & 1.001 \\
2008 & 150746 & 211 & 1.399 \\
2009 & 72823 & 69 & 0.947 \\
2010 & 20769 & 21 & 1.011 \\
\hline
\end{tabular}

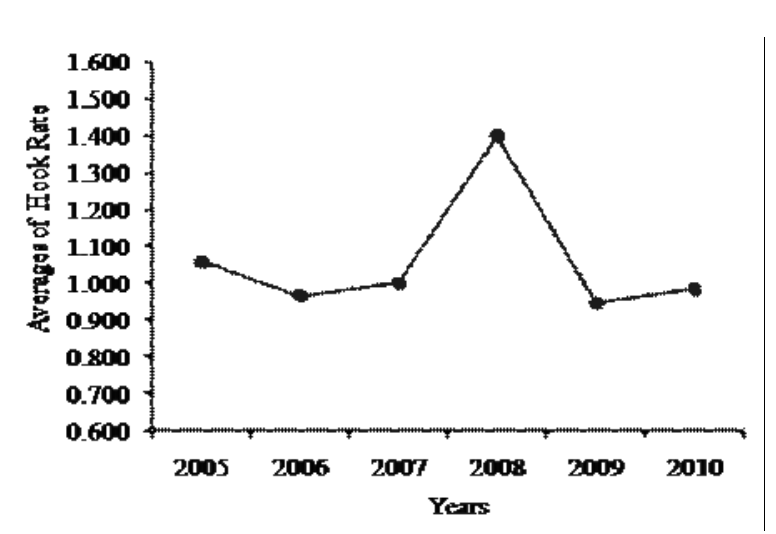

Figure 4. Hook rates fluktuation of wahoo on the tuna long line fisheries based at Benoa in 2006-2010.

\section{Fish Size}

The data of size (fork length-FL) of wahoo caught tuna long line tabulated by year in Table 2 . In 2006, the size ranged $72-180 \mathrm{~cm}$, in 2007 ranged $65-145$ $\mathrm{cm}$, in 2008 ranged $71-163$, in 2009 ranged $70-156 \mathrm{~cm}$ and in 2010 ranged $109-140 \mathrm{~cm}$. The overall (unsexed) shows that the modus of the size of wahoo was 101$110 \mathrm{~cm}$ as delineated on Figure 5 .

Table 2. Size of wahoo caught tuna long line based in Benoa during year 2006-2010.

\begin{tabular}{cccc}
\hline \multirow{2}{*}{ Years } & Number of & \multicolumn{2}{c}{ Fork length (cm) } \\
\cline { 3 - 4 } sample (fish) & Min & Max \\
\hline 2006 & 21 & 72 & 180 \\
2007 & 17 & 65 & 145 \\
2008 & 33 & 71 & 163 \\
2009 & 48 & 70 & 156 \\
2010 & 18 & 109 & 140 \\
\hline
\end{tabular}

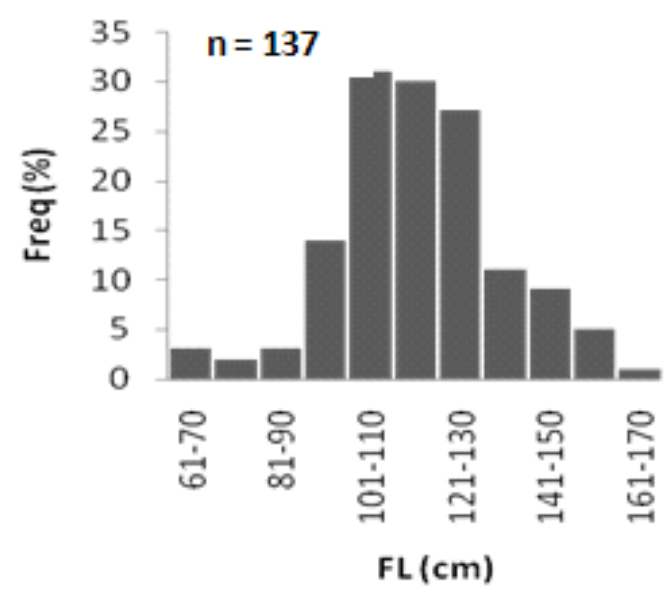

Figure 5. Size distribution of wahoo caught tuna long line based at Benoa in 2006-2010.

Sommer et al. (1996) noted that maximum total length (TL) of wahoo was $250 \mathrm{~cm}$ (unsexed), length at first maturity $L_{m}$ ranged $85-105 \mathrm{~cm}$ and the modus at $99.3 \mathrm{~cm}$ and according to Collette (1995) the common fork length was $170 \mathrm{~cm}$ (unsxed). Refer to this fact, the wahoo caught by tuna long line in Indian Ocean based in Benoa mostly were adult fish. This evidence is also ind icates the tuna long line was selective fishing gear for wahoo. 


\section{CONCLUSION}

From above description can be concluded as follows, the wahoo caught by tuna long line based at Benoa was between $1^{\circ} 31^{\prime} \mathrm{S}-33^{\circ} 40^{\prime} \mathrm{S}$ and $77^{\circ} 18^{\prime} \mathrm{E}$ $117^{\circ} 53^{\prime} \mathrm{E}$ and spreads between the depth of 75.2$285.7 \mathrm{~m}$. The hook rate ranged 0.947-1.399 per 1000 hooks/setting and mostly were adult fish.

\section{ACKNOWLEDGMENTS}

We express our thank to observers of Research Institute for Tuna Fishery Benoa Mr. Abram Barat, Mr. Dian Novianto, Mr.Andi Bachtiar, Mr.Gamadi, Mr. Yusuf Affandi, Mr. I Nyoman S., Mr. Irwan Jatmiko as well as Mr. I Gede Sanjaya who provided the data. We also thank to Director of RCMFC Purwanto, PhD for valuable inputs and comments.

\section{REFERENCES}

Bach, P., Dagorn, L., Bertrand, A., Josse, E., \& Misselis, C. 2003. Acoustic telemetry versus monitored longline fishing for studying the vertical distribution of pelagic fish: bigeye tuna (Thunnus obesus) in French Polynesia. Fisheries research, 60: 281-292.

Beverly,S. ,Curran D., Musyl M., \& Molonya B. 2009. Effects of eliminating shallow hooks from tuna longline sets on target and non-target species in the Hawaii-based pelagic tuna ûshery. Fish Res 96:281-288.

Kim, S.S., D.H. An, D.Y. Moon, \& S.J. Hwang, 2007. Comparison of circle hook and $\mathrm{J}$ hook catch rate for target and bycatch species taken in the Korean tuna long line fishery during 2005-2006. Scientific Committee Third Regular Session. 13-24 August 2007, Honolulu, United of America. WCPFC-SC3EB SWG/WP-11. $11 \mathrm{p}$.

Poisson. F. 2006. Compilation of information on neritic tuna species in the Indian Ocean. A Working Paper, IOTC Secretariat. IOTC-2006-SC-INF11. IOTC Ninth Session of the Scientific Committee, Mahé, Seychelles, 6-10 November 2006. 23 p.

Roullot, J. \& A. Venkatasami. 1986. Dispositifs de Concentration de Poissons (DCP): l'experience mauricienne. Doc. FAO. TWS/86/26. Expert consultation on the stock assessment of tunas in the Indian Ocean. Colombo , 4-8 December 1986. $12 \mathrm{p}$.
Garber A.F.,Tringali M.D., \& Franks J.S., 2005. Population genetic and phylogeographic structure of wahoo, Acanthocybium solandri, from the western central Atlantic and central Paciûc Oceans. Mar Biol. 147: 205-214.

Gillett, R. 2011. Bycatch in small-scale tuna fisheries. A global study. FAO Fisheries And Aquaculture Technical Paper No.560. Food And Agriculture Organization Of The United Nations, Rome. 116 p.

Collette, B.B. 1995 Scombridae. Atunes, bacoretas, bonitos, caballas, estorninos, melva, etc. In W. Fischer, F. Krupp, W. Schneider, C. Sommer, K.E. Carpenter and V. Niem (eds.) Guia FAO para Identification de Especies para lo Fines de la Pesca. Pacifico Centro-Oriental. 3 Vols. FAO, Rome. p. 1521-1543.

Collette, B.B. and C.E. Nauen. 1983. FAO Species Catalogue. Vol. 2. Scombrids of the world. An annotated and illustrated catalogue of tunas, mackerels, bonitos and related species known to date. FAO Fish. Synop. Rome: FAO. 125 (2): 137 p.

Sommer, C., W. Schneider and J.-M. Poutiers 1996. FAO species identification field guide for fishery purposes. The living marine resources of Somalia. $F A O$, Rome. $376 \mathrm{p}$.

Iverson, E. \& H. Yoshida. 1957. Notes on the biology of the wahoo in the Linde Islands. Pacific Science. 11: 370-379.

Nakano, H., M. Okazaki \& O. H. 1997. Analysis of catch depth by species for tuna longline fishery based on catch by branch lines. Bull Nat Res Inst Far Seas Fish. 34: 43-62.

NMFS. 2001. Final Environmental Impact Statement: Pelagic Fisheries of the Western Pacific Region. Prepared by: URS Corporation, 615 Pi'ikoi St, Ste 900, Honolulu HI 96814. Southwest Fisheries Science Center, NMFS/NOAA. Available online: http://swr.nmfs.noaa.gov/piao/eisdocs.htm.

Stevens, M.M. 2004. Wahoo/Ono, Acanthocybium solandri. Wahoo_Pacific_SFW_MMS_Final Report.doc. Seafood Watch-Seafood Report. Monterey Bay Aquarium.

Mc Bride R.S., Richardson A.K.,Maki K.L. 2008. Age, growth, and Mortality of wahoo, Acanthocybium solandri, from the Atlantic coast of Florida and the Bahamas. Mar Fresh Res. 59:799-807. 
Ind.Fish.Res.J. Vol.18 No. 2 Desember 2012 : 101-106

Sepulveda C.A., ScottA. Aalbers, Soûa Ortega Garcia, Nicholas C.Wegner \& Diego Bernal. 2011. Depth distribution and temperature preferences of wahoo (Acanthocybium solandri) off Baja California Sur, Mexico. Mar Biol. 158:917-926. 